\author{
파두유를 주입한 육계병아리에서 사료중 크릴밀 수준이 세포성 \\ 면역에 미치는 영향 \\ 임진택 · 박인경 · 고태송 \\ 건국대학교 동물생명과학대학 동물생명과학부
}

\title{
Effect of Dietary Krill Meal Levels on the Cell Mediated Immunity in Intra-muscularly Croton Oil Injected Broiler Chicks
}

\author{
J. T. Im, I. K. Park and T. S. Koh \\ Department of Animal Life Sciences, College of Animal Life Sciences, Konkuk University, Seoul \\ 143-701, Korea
}

\begin{abstract}
Effect of dietary krill meal levels on the cellular immunity was studied in broiler chicks activated immune response. One day old male broiler chicks (Ross) were fed the experimental krill meal 0.0 (basal), 0.5, 1.0 and 2.0\% diets for 3wks. Blood TNF-a activity, ovotransferrin level and Con A induced proliferation of PBMC and splenocytes after $24 \mathrm{hr}(21 \mathrm{~d}$ age $)$ of the croton oil $10 \mu l$ injection intramusculary at the age of 20 days compared to the control olive oil. Krill meal diets did not affect growth performance of broiler chicks and plasma ovotransferrin levels but decreased significantly $(\mathrm{p}<0.0001)$ TNF-a like activity and proliferation of PBMC relative to krill meal $0.0 \%$ diet. And the proliferation of splenocytes were significantly $(\mathrm{p}<0.05)$ increased in birds fed krill meal $1.0 \%$ diet relative to krill meal 0.5 and $2.0 \%$ diets. The croton oil injection induced a significant $(\mathrm{p}<0.0001)$ increases in the TNF- $a$ activity or the PBMC proliferation and enhanced circulating ovotransferrin levels relative to the olive oil. In birds injected with the croton oil the proliferation of PBMC was reduced linearly with the increase of dietary krill meal levels, and the proliferation of splenocytes was decreased in the krill meal 1.0 and $2.0 \%$ diets relative to olive oil. These results indicated that dietary krill meal changed the innate and cellular immunity in broiler chicks activated by the injection of croton oil.

(Key words : Croton oil, Tumor necrosis factor-a (TNF-a), Proliferation of PBMC and splenocytes, Krill meal, Broiler chicks)
\end{abstract}

$$
\text { I. 서 론 }
$$

동물에서 세균등 외부 항원에 노출된 감염부 위의 대식세포(macrophage)나 헤테로필(heterophyl) 등 면역세포들은 친 염증성 싸이토카인(Cytokine) 인 interleukin-1(IL-1), interleukin-6(IL-6), 또는 tumor necrosis factor-a (TNF-a)들을 분비한다. 이 싸이토카인들은 동물체에서 발열, 사료섭취 감소 및 간장의 급성기 단백질 합성 증가의 신 호가 되고(Leshchinsky와 Klasing, 2001; Klasing, 1994), 동물은 이러한 선천 면역반응 활성화(급 성기 염증 반응)에 대하여 생리적 및 대사적

Corresponding author : Koh, T. S. Department of Animal Life Sciences, Konkuk University, Gwangjin-gu, Seoul 143-701, Korea.

Tel : 82-02-450-3698, Fax : 82-02-455-1044, E-mail : tskoh@konkuk.ac.kr 
항상성 조정으로 적응하고 생산성이 낮아진다 (Korver와 Klasing, 1997 Xie 등, 2002). 영양은 질병원에 대한 양적 및 질적 면역반응을 조정 하고, 사료가 면역성에 미치는 영향이 가금을 이용한 연구에서 잘 설명되어 있다(Cook, 1991; Koutosos와 Klasing, 2001).

사료중 크릴 밀은 육계 병아리의 선천면역 반응과 세포성 면역 그리고 항산화계에 영향을 미첬다. 복강내LPS 주입으로 급성염증 (선천면 역) 반응이 활성화한 육계병아리에서, 크릴 밀 0.5 및 $1.0 \%$ 사료는 증체량을 감소시켰으나, 염 증반응에서 회복중에는 생산성 감소를 완화시 켰다 (고 등, 2004). 또한 사료중 크릴 밀의 낮 은 질소밸런스는 체단백질의 분해 (뇨산배설량) 에 기인하였고 크릴 밀사료의 높은 $\mathrm{ME}$ 값은 사료 에너지원의 흡수가 염증반응으로 많아지 는데 기인하였다 (임 등, 2003).

그리고 크릴 밀의 종류(박 등, 2004)에 따라 간 세포액의 CuZnSOD 활성이 달랐으며, 적혈 구 세포액중의 $\mathrm{MnSOD}$ 와 $\mathrm{CuZnSOD}$ 활성은 사 료중 크릴 밀 수준 (고 등, 2004)에 따라 높아 졌다.

급성기 염증 반응에서 회복 또는 이러한 경 험이 없는 육계병아리에서, 크릴 밀 사료는, 사 료중 크릴 밀 수준(고 등, 2004)이나 종류(박 등, 2004)와 관계없이, PHA-p (phytohemagglutininp) 반응을 높이는 경향을 보였다. 그리고 LPS 주입 급성기 염증 반응중인 육계병아리에서, 임 등 (2007)은 크릴 밀 사료는 사료중 크릴밀 함량과 관계없이 혈장 TNF- $a$ 를 감소시키고, 크 릴 밀 $0.0 \%$ (기초) 사료에 비해, Con A 자극 $\mathrm{PBMC}$ 와 비장세포의 증식도는 크릴 밀 $0.5 \%$ 사료에서 유의하게 증가하나, 크릴 밀 1.0 및 $2.0 \%$ 사료에서는 감소하는 것을 관찰하였다. 그러나 급성기 염증반응이 유도되지 않은 육계 병아리에서는 크릴 밀 수준이 높아짐에 따라 Con A 자극 PBMC 와 비장세포의 증식도가 증 가 하였다(임 등, 2007). 이러한 결과들은 사료 중 크릴 밀의 농도에 따라 육계병아리의 타고 난 면역과 세포성 면역에 미치는 크릴밀의 영 향이 다르다는 것을 나타내고 있다.

인체 및 동물의약품 산업에서 독성이 있는
표준 배변자극제로 오랫동안 사용되어온 파두 유 (Croton oil) (Pettit, 1977)는 동물체에서 LPS 또는 테레빈유 (turpentine oil)의 작용과 비슷하 게 급성기염증 (면역) 반응을 활성화하는데 사 용된다 (Heuertz 등, 1993; Tohjo 등, 1995). 가금 에서 LPS 보다 가격이 저렴한 파두유의 근육 내 주입은 급성기 염증 반응을 지속적으로 활 성화 시키고 혈중 IL-6 (interleukine-6) 분비를 높이고, 간장으로부터 혈중 오보트렌스훼린 분 비를 증가시킨다 (Xie 등, 2002).

따라서 본 연구는 육계병아리에서 사료중 크 릴 밀 농도가 세포성 면역에 미치는 영향을 확 인하기 위하여 실시 되었다. 크로톤 오일 주입 에 의한 급성기 염증 반응이 활성화한 육계 병 아리에서 혈액중 TNF- $a$ 활성과 오보트스페린 수준 및 $\mathrm{PBMC}$ 와 비장세포의 증식도를 조사 하였다.

\section{․ 재료 및 방법}

\section{1. 공시동물, 실험설계 및 실험사육}

갓 부화된 육계 병아리(Ross) 수컷 120수를 1 일령부터 기초사료(Table 1)와 기초사료 중 대 두박대신 $0.5,1.0$ 및 2.0\%의 크릴 밀이 대치된 네 종류의 실험사료를 급여하여 3주간 사육하 였다. 육계 병아리는 경기도에 소재한 부화장 에서 부화즉시 수거하여 자웅 감별후 사용하였 으며 어떤 백신도 접종되지 않았다. 육계병아 리는 한 사료당 각각 6 개 우리를 할당하고 우 리당 5마리씩 24개 우리로 나누어 온도가 조절 되는 사육실에서 사육하였다. 물과 사료는 자 유로 섭취하게 하였다. 각 시험구의 절반인 3 개 우리의 20 일 령 병아리의 정강이 근육에 1 수당 $100 \mu \mathrm{e}$ (파두유 $10 \mu \mathrm{g} /$ 수)씩 파두유를 주입 하였다(Xie 등, 2002). 면역원인 파두유 (10\%)는 올리브오일(Sigma, USA)과 파두유(Sigma, USA) $9: 1$ 비의 혼합액이다. 대조는 각 사료당 나머 지 절반인 3 개 우리에 올리브유를 1 수당 100

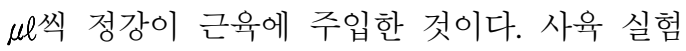
중, 병아리 무게는 7일, 14 일 및 21일령에 측정 하였고, 사료섭취량은 24시간 간격으로 매일 
Table 1. Composition $(\mathrm{g} / \mathrm{kg})$ of basal diet and experimental diet (NRC, 1994)

\begin{tabular}{lc}
\hline Ingredients & Basal \\
\hline \hline Ground yellow corn (8.8\% Protein) & 596 \\
Soybean meal (48.5\% Protein) & 355 \\
DL-Methionine & 2.5 \\
Soybean oil & 5.0 \\
Choline $\mathrm{HCl}(50 \%)$ & 1.5 \\
(Iodized) Salt $_{\text {CaCO }}$ & 5.0 \\
CaHPO & $2 \mathrm{H}_{2} \mathrm{O}$ \\
Vitamin mix $^{1)}$ & 10.0 \\
Mineral mix & 20.0 \\
Krill meal $^{2)}$ & 2.5 \\
\hline
\end{tabular}

\begin{tabular}{l}
\hline Total $1,000 \mathrm{~g}$ \\
\hline${ }^{1)}$ Vitamin mix provided the following per kg diet \\
vitamin $\mathrm{K} 0.55 \mathrm{mg}$, antioxidant $125 \mathrm{mg}$, vitamin $\mathrm{E}$ \\
$10 \mathrm{IU}$, vitamin $\mathrm{D}_{3} 400 \mathrm{IU}$, vitamin A $1,500 \mathrm{IU}$, \\
biotin $0.15 \mathrm{mg}$, folacin $0.55 \mathrm{mg}$, pyridoxine $\mathrm{HCl} 3$ \\
mg, niacin $25 \mathrm{mg}$, Calcium panthothenate $10 \mathrm{mg}$, \\
Riboflavin $3.6 \mathrm{mg}$, Thiamin $\mathrm{HCl} 1.8 \mathrm{mg}$. \\
Mineral mix provided the following per kg diet \\
MnSO $\mathrm{H}_{2} \mathrm{O} 170 \mathrm{mg}, \mathrm{ZnSO}_{4} \mathrm{H}_{2} \mathrm{O} 110 \mathrm{mg}$, Ferric \\
citrate $500 \mathrm{mg}, \mathrm{CuSO}_{4} \mathrm{5H}_{2} \mathrm{O} 16 \mathrm{mg}, \mathrm{Na}_{2} \mathrm{SeO}_{3} 0.2$ \\
mg.
\end{tabular}

정해진 시각에 사료 급여와 잔량 기록으로 계 산하였다.

\section{2. 혈장과 $\mathrm{PBMC}$ 분리, 간장과 비장 무게 및 비장세포 분리}

파두유 주입 24시간 (21일령) 뒤에 각 우리에 서 임의 선발한 육계병아리의 무게를 측정 후 심장천자로 $3 \mathrm{ml}$ 의 혈액을 취하고, 경추골 분리 로 희생시켰다. 혈액은 $3,000 \mathrm{rpm}$ 에서 15 분간 원심하여 상등액인 혈장은 $0.22 \mu \mathrm{m}$ 필터로 여과 멸균하고 혈중 TNF-a 활성과 오보트렌스훼린 분석에 이용할 때까지 $-80^{\circ} \mathrm{C}$ 에 보관하였다. 채 혈 후 육계 병아리의 복부를 절개하여 적출한
간장과 비장은 사료 급여구 별로 $0.9 \%$ 염용액 으로 3회 세척하고 무게를 측정하였다.

육계병아리 (21일령)의 혈액을 $15 \mathrm{ml}$ 튜브에 서 멸균 $\mathrm{PBS}(\mathrm{pH}$ 7.4)로 2배 희석하고 동량의 비중액 (Histopaque, Density $=1.077 \mathrm{~g} / \mathrm{ml}$, Sigma Co., USA)을 넣어 2,000 rpm(800×g)에서 15분간 원심하였다. 비중액과 $\mathrm{PBS}$-혈장 혼합액의 중간 에 형성된 buffy coat층을 취하여 FBS 5\% RPMI-1640 배양액 (배양액)에 현탁하였다. 현탁 액은 같은 방법으로 2회 세척한 뒤에 1,200 $\mathrm{rpm}$ 에서 10 분간 원심하여 얻은 펠렛층은, 배양 액으로 현탁하여 현미경과 Hemacytometer로 세 포수를 세고, 배양액으로 $\mathrm{ml}$ 당 $\mathrm{PBMC} 2.0 \times 10^{6}$ 개 세포로 조정한 현탁액을 얻었다.

페트리접시에 넣은 비장위에 직경 $200 \mu \mathrm{m}$ 나 일론 망을 얹은 후 배양액 $3 \mathrm{ml}$ 를 넣어 주사기 피스톤의 앞부분으로 비장을 으깨었다. 흘러나 온 비장세포 현탁액을 주사기로 흡입 후 나일 론 망위에 세게 분사하여 결합조직으로부터 비 장세포를 분리하였다. 비장세포 현탁액은 15 $\mathrm{ml}$ 튜브에서 동량의 비중액 (Histopaque, Sigma Co., USA)을 넣고, $2,000 \mathrm{rpm}(800 \times \mathrm{g})$ 에서 15 분 간 원심하였다. 원심 후 비중액과 배양액 사이 의 buffy coat층 함유 배양액을 배양액에 현탁 하였다. 비장세포 현탁액을 $1,200 \mathrm{rpm}$ 에서 10 분 간 원심하여 얻은 비장세포 펠렛층은 배양액 3 $\mathrm{ml}$ 에 현탁하여 세포수를 세고 $\mathrm{ml}$ 당 $2.0 \times 10^{6}$ 개 비장세포로 조정하였다.

\section{3. 혈중 TNF-a 활성}

혈장과 혼합 배양한 L929 세포주의 괴사정도 를 rh TNF-a (Sigma Co., USA)의 그것과 비교 하여 TNF-a 활성을 평가하였다 (Flick과 Gifford, 1984). 96웰 플레이트의 웰당 $2.5 \times 10^{4} \mathrm{~L} 929$ 세 포 $(100 \mu \ell)$ 를 접종하고 $37^{\circ} \mathrm{C}$ 와 $\mathrm{CO}_{2} 5 \%$ 에서 24 시간 배양하였다. 배양액을 제거하고 각 웰에 TNF-a (Sigma Co., USA) 표준용액 (5 ng/100 $\mu \ell)$ 또는 5배 희석 혈장 $100 \mu \ell$ 를 넣었다. TNF-a 표준용액은 TNF-a 량이 웰당 $2.44 \mathrm{pg}$ 이 될 때 까지 연속 희석하였다. 모든 웰에 Actinomycin $\mathrm{D}$ (Sigma Co., USA) $10 \mu \ell(0.2 \mu \mathrm{g})$ 를 넣고 $37^{\circ} \mathrm{C}$ 
와 $\mathrm{CO}_{2} 5 \%$ 에서 20 시간 배양한 다음 웰당 10 $\mathrm{uL}(10 \%)$ 의 alamar blue (Serotec, USA)를 넣고 4 시간 더 배양하였다. 혈장내 TNF-a 활성은 ELISA 리더 (Biotek, USA)로 $570 \mathrm{~nm}$ 에서 600 $\mathrm{nm}$ 의 광학밀도 값을 뺀 값을 rh TNF-a에서 얻 은 표준곡선 값에 대입하여 계산하였다.

\section{4. 혈장 오보트렌스훼린}

급성기 반응중인 육계병아리 (21일령)의 혈장 을 10 배 희석 혈장내 단백질들은 SDS가 함유 되지 않은 비환원 시료완충액에서 acrylamide $10 \%$ 젤에 전기영동 (SDS-PAGE: sodium dodecyl sulfate polyacryl amide gel electrophoresis)하여 전개시켰다. 쿠마시블루용액으로 염색한 후 젤 상에 나타난 단백질 밴드들 중에서 분자량 65 $\mathrm{kDa}$ 단백질의 농도를 영상분석장치 (image analyzer, Vilber lourmat, France)의 농도계법으로 측정하 였다(임 등 2007). SDS-PAGE 젤상의 혈장단백 질을 $\mathrm{NC}$ 막 (nitrocellulose membrane)에 이전시킨 뒤 TBST(tris buffered saline with tween 20)로 1,000 배 희석한 항-가금 ovotrasferrin 항체 (anti-chicken ovotransferrin antibody from rabbit serum, Acurate chemical, AIA8240)와 결합시켰 다. NC막의 혈장 단백질들은 다시 secondary antibody 용액 (monoclonal anti-rabbit IgG 8 -chain specific peroxidase conjugated, Sigma Co., A1949)과 결합시켰다. 암실에서 Hyper film (Amersham, HP7 9NA)을 이용하여 ECL 용액으 로 발광하는 항체 특이적으로 반응한 분획 $(65 \mathrm{kDa})$ 이 ovotransferrin이므로 앞서 영상분석장 치로 정량한 그 밴드를 ovotransferrin 농도로 하 였다 (Xie 등, 2002).

\section{5. $\mathrm{PBMC}$ 와 비장세포증식도}

$\mathrm{PBMC}$ 와 비장세포의 증식도는 알라마 블루 (alamar blue) 색소의 환원량(임 등, 2007)으로 평가하였다. 혈액에서 분리한 PBMC 현탁액 50 $\mu \ell\left(10^{5}\right.$ 개)를 96 웰 플레이트의 각 웰에 접종하여 $37^{\circ} \mathrm{C}$ 와 $\mathrm{CO}_{2} 5 \%$ 에서 배양하였다. 배양 4 시간
째 웰당 Concanavalin A용액 (Con A, $10 \mu \mathrm{g} / \mathrm{ml}$ ) $40 \mu$ 씩을 넣고, 20 시간째에 $10 \mu \ell(10 \%)$ 의 alamar blue를 첨가하여 4시간 더 배양하였다.

비장세포 현탁액은 96웰 플레이트에 웰당 50 $\mu \ell\left(10^{6}\right.$ 개)씩 넣고 $37^{\circ} \mathrm{C}$ 와 $\mathrm{CO}_{2} 5 \%$ 에서 배양하 였다. 배양 12시간째에 모든 웰에 Con A용액 $(10 \mu \mathrm{g} / \mathrm{ml}) 40 \mu \ell$ 를 넣고, 배양 24시간째 alamar blue(10\%) $10 \mu \ell$ 를 첨가하여 24시간 더 배양하 였다. PBMC 또는 비장세포의 증식도는 광학밀 도(OD) $570 \mathrm{~nm}$ 에서 $600 \mathrm{~nm}$ 를 뺀 값이다.

\section{6. 통계처리}

실험데이터는 파두유 주입과 크릴 밀 사료 수준의 2원배치 분산분석을 SAS 프로그램의 GLM법으로 주효과 및 상호관계를 조사하였다. 주효과가 유의하면 $(\mathrm{p}<0.05)$, 평균값 사이의 유 의차는 Duncan의 다중검정과 Student's t 값으로 검정하였고, $\mathrm{p}<0.10$ 값은 경향을 나타내는 것으 로 하였다.

\section{III. 결 과}

\section{1. 생산성과 장기 무게}

크릴 밀 0.5, 1.0 및 2.0\% 사료가 육계 병아 리의 생산성과 파두유의 근육내 주입이 간장과 비장 무게에 미치는 영향을 Table 2에 나타내 었다. 육계병아리를 21일간 사육했을 때 일당 증체에 미치는 사료중 크릴 밀 수준의 유의한 영향은 없었다. 그러나 크릴 밀 $2.0 \%$ 사료를 급여한 육계병아리에서 크릴 밀 0.5 및 $1.0 \%$ 사료에 비해 사료섭취량은 유의하게 높고 $(\mathrm{p}<$ $0.05)$ 사료효율은 낮아지는 경향이 있었다.

육계병아리에 파두유 주입은 사료중 크릴 밀 수준과 관계없이 파두유 주입 24시간(21일령) 뒤 체중에 대한 간장과 비장의 무게 비율을 올 리브유 주입 대조구에 비해 높이는 경향을 보 였다. 그러나 사료중 크릴 밀 수준이 간장과 비장무게에 미치는 영향은 측정수가 적어서 통 계적인 평가는 이루어지지 않았다. 
Table 2. Effect of dietary krill meal on growth performance of broiler chicks during 21 days of experimental feeding period and relative weights of liver and spleen after 24 hour by croton oil injection i.m.

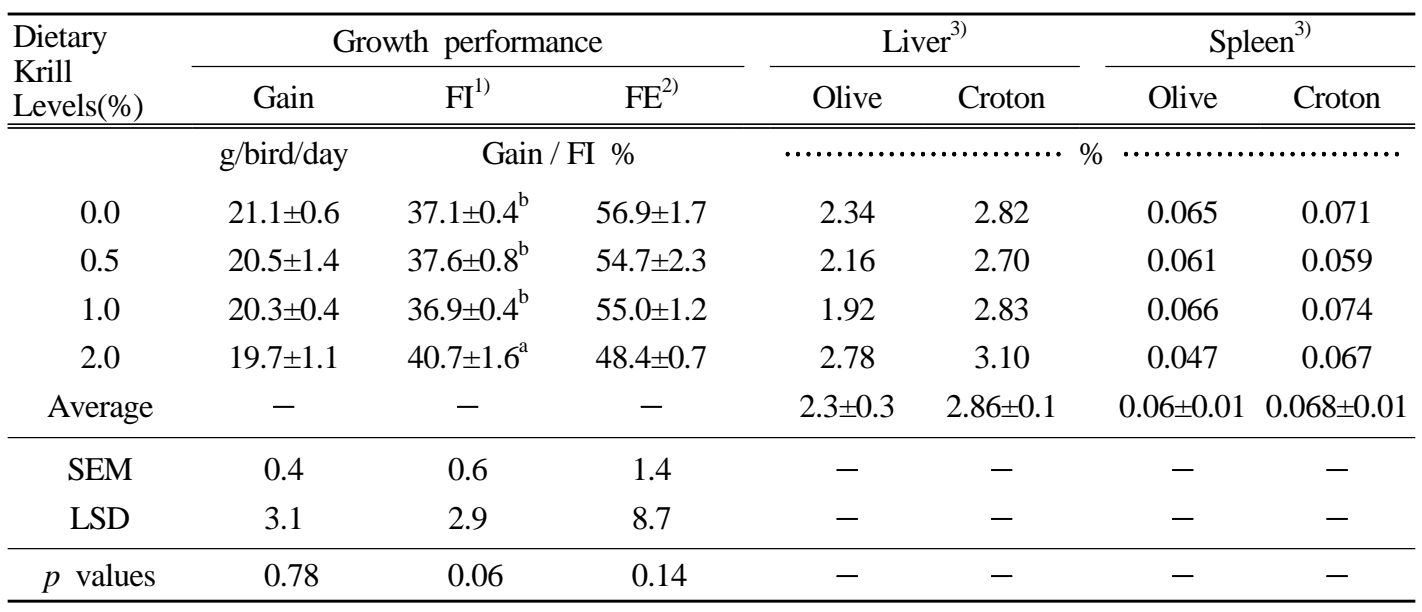

Values of gain, FI, and FE are mean \pm SE of six pens (5 birds/pen).

1) $\mathrm{FI}=$ feed intake, ${ }^{2)} \mathrm{FE}=$ feed efficiency ${ }^{3)}$ Pooled values(3 birds (pen) on a diet)

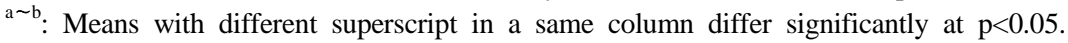

\section{2. 혈중 TNF-a 활성}

육계 1녕아이키에서 파두유의 근육내 주입에 의 한 급성기 반응중 혈중 TNF-a 활성에 미치는

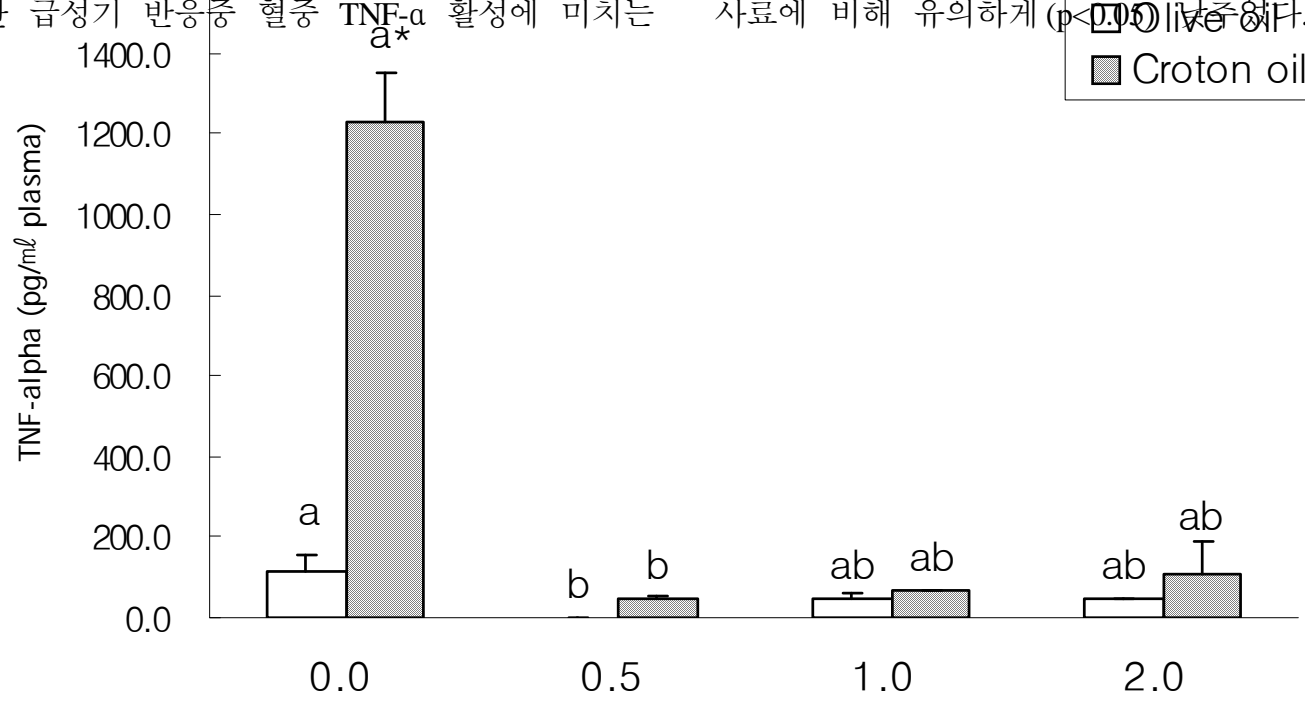

Dietary kril level (\%)
사료중 크릴 밀의 영향을 Fig. 1에 나타내었다. 크릴 밀 사료는 파두유 및 올리브유 주입에 관 계없이 육계병아리의 혈중 TNF-a 활성을 기초

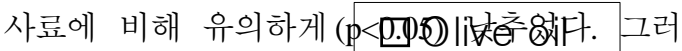


나 TNF-a 활성은 사료중 크릴 밀 수준사이에 유의한 차이가 없었다. 크릴 밀 $0.0 \%$ 사료를 섭취한 육계병아리에서 파두유 주입은 혈중 TNF-a의 활성을 올리브유 주입구에 비해 유의 하게 증가시켰다 $(\mathrm{p}<0.05)$. 그러나 크릴 밀 사료 를 급여한 육계병아리에서는 TNF-a 활성이 파 두유 주입과 올리브유 주입 사이에 유의한 차 이가 없었다.

\section{3. 혈중 오보트렌스페린 수준}

육계병아리의 혈액 단백질을 SDS-PAGE로 분리하고 쿠마시블루로 염색한 결과를 Fig. 2에 나타내었다. 단백질 $65 \mathrm{kDa}$ 밴드가 항-가금 오보트렌스훼린 항체와 결합하여 이것이 오보 트렌스훼린으로 확인되었다. 영상분석장치로 65
$\mathrm{kDa}$ 오보트렌스훼린 분획의 수준을 측정한 결 과를 Fig. 2(B)에 함께 나타내었다. 파두유 주입 은 혈중 오보트렌스훼린 수준을 사료의 종류에 관계없이 증가시켰다. 크릴 밀 $0.0 \%$ 사료 급여 시 파두유 주입은 올리브유 주입 대조구에 비 해 오보트렌스훼린 수준을 약 $60 \%$ 증가시키나, 크릴 밀 사료 급여시에는 사료중 크릴 밀 수준 에 관계없이 20 30\% 증가하였다. 한편 올리브 유 주입 대조구에서는 사료중 크릴 밀 수준에 따라 혈중 오보트렌스훼린 수준이 높아지는 경 향을 보였다.

\section{4. $\mathrm{PBMC}$ 와 비장세포 증식도}

Table 3에는 PBMC 와 비장세포 증식도에 미 치는 사료, 파두유 주입 및 사료와 파두유 주

(A)

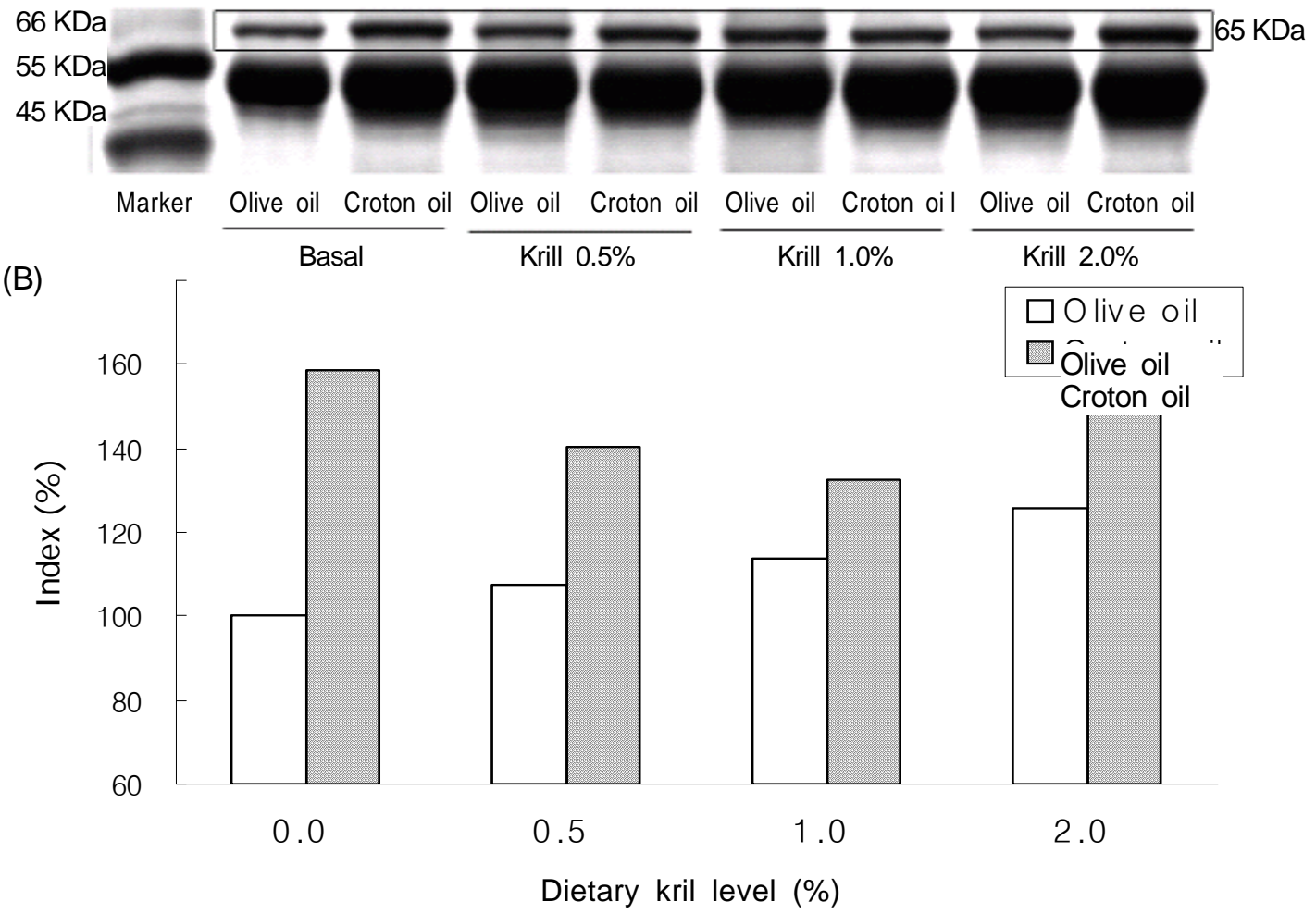

Fig. 2. Effect of dietry krill meal on plasma protein profile and ovotransferrin level in plasma of male broiler chicks after $24 \mathrm{~h}$ of croton oil injection i.m.. (A) : Plasma protein profile, (B) Ovotransferrin (65 kDa) level. Values are index to the level in blood of normal chicks fed basal diet. 
Table 3. $p$ values for factorial analysis in effect of dietary krill meal levels on TNF-a like activity and proliferation of PBMC and splenocyte

\begin{tabular}{lccc}
\hline & TNF-a & PBMC & Splenocyte \\
\hline \hline Diet & $<.0001$ & $<.0001$ & 0.03 \\
Croton oil & $<.0001$ & $<.0001$ & 0.01 \\
Diet $\times$ Croton oil & $<.0001$ & $<.0001$ & 0.0007 \\
\hline
\end{tabular}

입의 상호작용에 관한 요인 분석결과를 나타내 었으며, 이들 요인들의 영향이 모두 유의하였 다. 파두유 주입 24시간 (21일령) 뒤에 육계병아 리에서 Con A $(10 \mu \mathrm{g} / \mathrm{ml})$ 로 자극한 PBMC 증식 도에 미치는 크릴 밀 사료의 영향을 Fig. 3에 나타내었다. 파두유 주입은 대조보다 크릴 밀 $0.5,1.0$ 및 $2.0 \%$ 사료를 급여하면 $\mathrm{PBMC}$ 증식 도를 유의하게 $(\mathrm{p}<0.05)$ 높였다. 크릴 밀 $0.0 \%$ (기초) 사료를 급여하면 파두유와 올리브유 사 이에 유의차가 없었다. 파두유 주입 육계병아 리에서 크릴 밀 사료는 기초사료보다 PBMC 증식도를 유의하게 $(p<0.05)$ 높였다. 한편 사료 중 크릴 밀 수준이 $0.5,1.0$ 및 $2.0 \%$ 로 높아짐 지면 파두유 주입 육계병아리의 PBMC 증식도
는 점차 유의하게 $(\mathrm{p}<0.05)$ 감소하였다. 그러나 올리브유 주입 육계병아리에서 PBMC 증식도 는 크릴 밀 $0.5 \%$ 사료에 비해 크릴 밀 1.0 및 $2.0 \%$ 사료에서 유의하게 $(\mathrm{p}<0.05)$ 높았다.

파두유 주입 육계병아리에서 Con A (10 $\mu \mathrm{g}$ $/ \mathrm{ml}$ ) 자극 비장세포 증식도에 미치는 사료중 크 릴 밀 수준의 영향을 Fig. 4에 나타내었다. 비 장세포증식도는 파두유 주입으로 올리브유 주 입보다 크릴 밀 $0.0 \%$ 사료에서 유의하게 높았 고, $0.5 \%$ 사료에서 유의차가 없었으며, 1.0 및 $2.0 \%$ 사료에서는 유의하게 $(\mathrm{p}<0.05)$ 낮았다. 파 두유 주입 육계병아리에서 크릴 밀 0.0 및 $0.5 \%$ 사료는 1.0 및 $2.0 \%$ 사료보다 비장세포 증식도를 유의하게 $(\mathrm{p}<0.05)$ 높였다. 올리브유

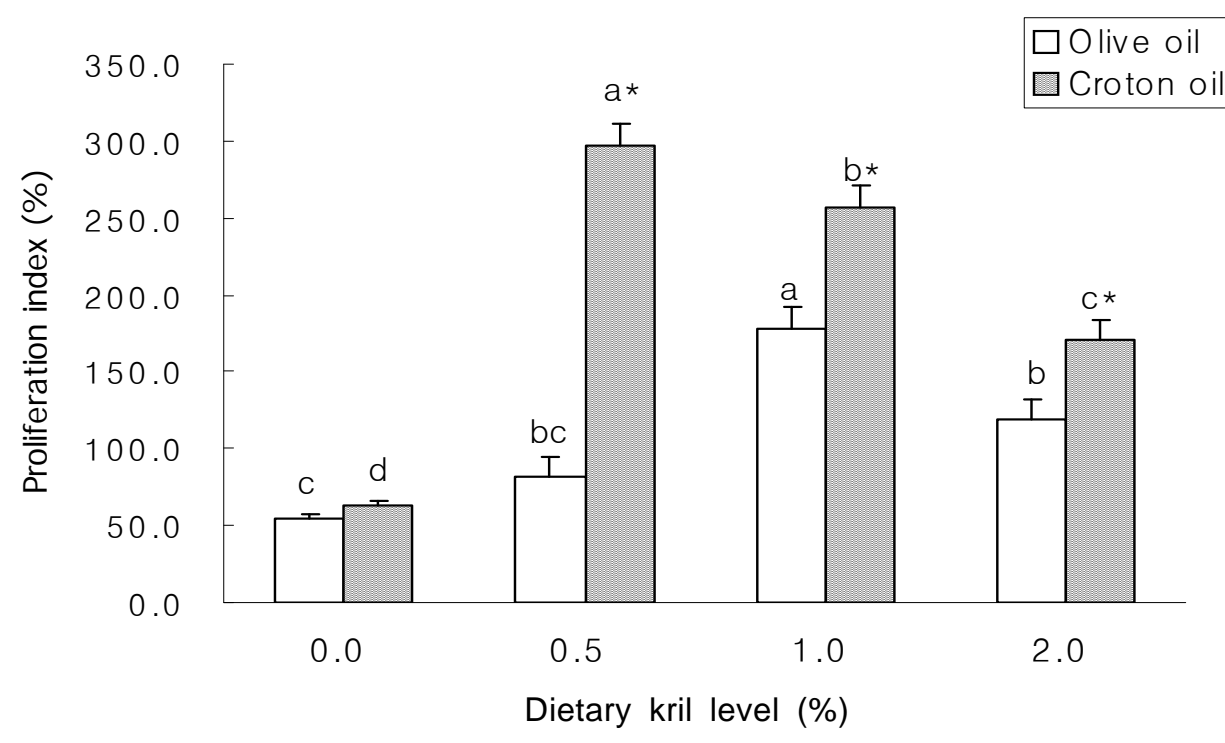

Fig. 3. Effect of dietary krill meal on the proliferation of PBMC of male broiler chicks after 24 $\mathrm{h}$ of croton oil injection i.m.. Values are mean \pm SE of 3 birds. Values are indices of Con A treatment as differences between 570 and $600 \mathrm{~nm}$ optical density to without Con A treatment incubation during incubation of PBMC of birds fed basal diet. ${ }^{a \sim b}$ : Means with different superscript among krill levels in same treatment, and * : means between olive oil and croton oil in a same diet differ significantly at $p<0.05$, respectively. 


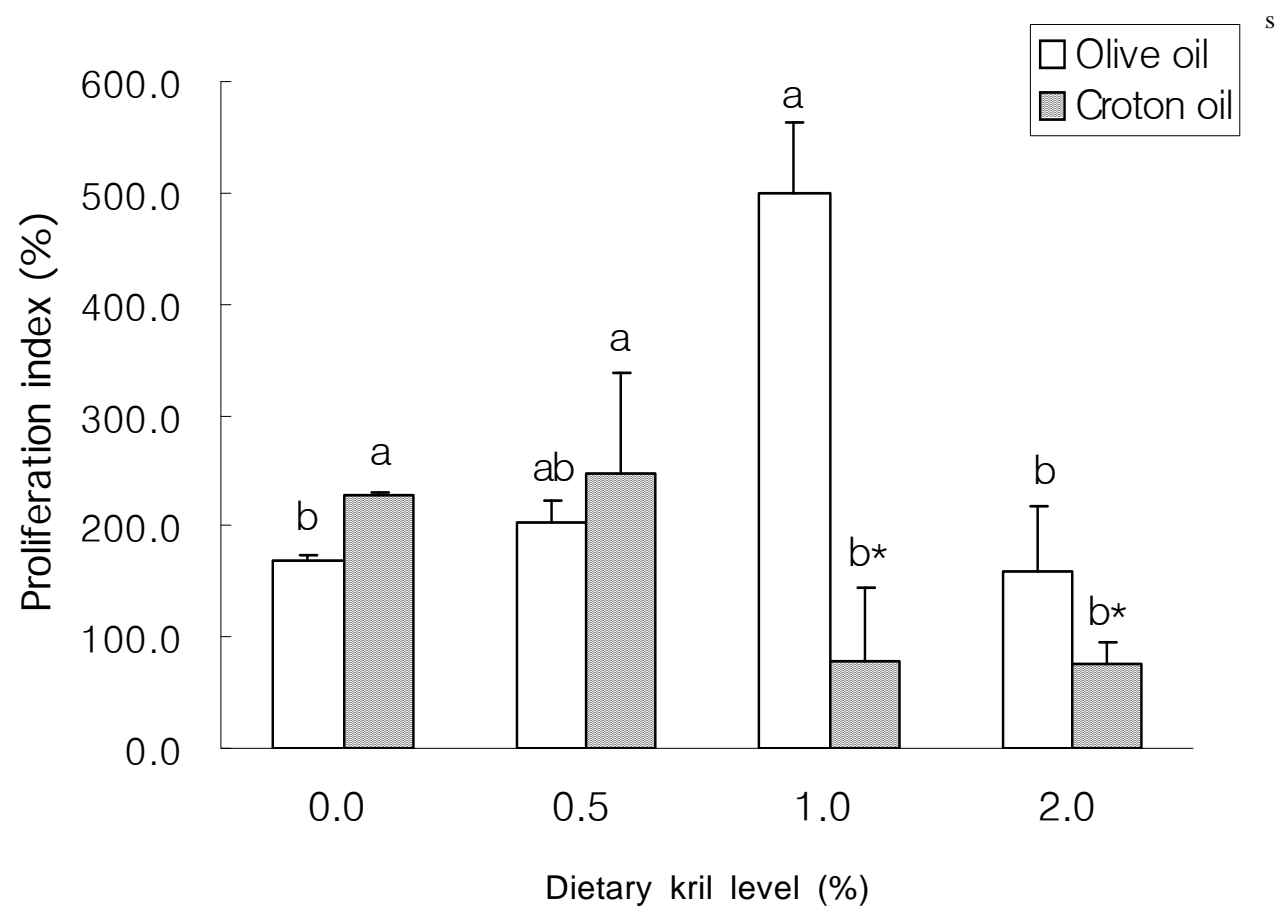

Fig. 4. Effect of dietary krill meal on the proliferation of splenocyte of male broiler chicks after $24 \mathrm{~h}$ of croton oil injection i.m. Values are mean \pm SE of 3 birds. Values are indices of Con A treantment as differences between 570 and $600 \mathrm{~nm}$ of optical density to without con A treatment during incubation of splenocyte of birds fed basal diet. $^{a \sim b}$ : Means with different superscript among krill levels in same treatment, and * : means between olive oil and croton oil in a same diet differ significantly at $\mathrm{p}<0.05$, respectively.

주입 육계병아리에서, 크릴 밀 $1.0 \%$ 사료의 비장세포 증식도는 $0.5 \%$ 사료 사이에 차이가 없었으나 기초사료와 크릴 밀 $2.0 \%$ 사료급여에 비하여는 유의하게 높았다 $(\mathrm{p}<0.05)$.

\section{IV. 고 찰}

파두유(巴豆油: croton oil)는 주로 스테아린 산, 팔미친 산, 미리스친 산, 라우린 산의 글리 세롤 ester (glycerides)로 구성되며, 휘발성 산인 formic, acetic, 및 isobutyric acid의 glycerin ether 를 함유한다. 그리고 파두유의 활성성분은 알 콜에 잘녹는 크로톤산 (crotonic acid)로 여겨지 고 있다(Fig. 5).

파두유에서 발견되는 크로톤산은 단쇄불포화 carboxylic acid의 하나로 계통명은 IUPAC계로 trans-2-butenoic acid이고, acrylic acid계로는 3-methyl acrylic acid이다. 백색에서 미백색결정 으로 물에 잘 녹고, 수용액은 약산성이며, 융점

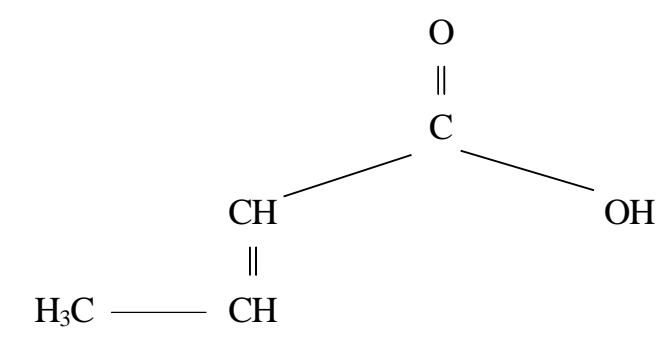

Fig. 5. Structure of crotonic acid.

은 $71^{\circ} \mathrm{C}$ 이고 $185^{\circ} \mathrm{C}$ 에서 끓으며, 염기, 산화제 및 환원성 제제와 강렬하게 반응한다. 파두유 는 약리학적으로 인체 및 동물의약품 산업에서 독성이 있는 표준 배변자극제로 오랫동안 사용 되어 왔다(Pettit, 1977). 파두유는 LPS 또는 테 레빈유 (turpentine oil)와 같이 동물체의 선천 면 역 (급성기) 반응의 유도에 사용된다 (Heuertz 등, 1993; Tohjo 등, 1995). 파두유는 LPS에 비 해 가격이 저렴하며 급성기 염증 반응을 지속 적으로 유도한다고 알려져 있다 (Xie 등, 2002). 


\section{1. 생산성 및 간장과 비장무게}

사료중 크릴 밀 수준이 육계병아리에서 21일 간의 일당 증체에는 큰 영향을 미치지 않았으 나 육계병아리는 크릴 밀 $2.0 \%$ 사료를 유의하 게 많이 섭취하였고, 이 때 사료효율은 감소되 는 경향을 보였다. 임 등 $(2003,2007 b)$ 과 박 등 (2004)도 크릴 밀 $2.0 \%$ 사료의 섭취량이 크릴 밀 $0.0 \%$ (기초) 사료보다 높고 사료효율이 낮아 지는 것을 관찰하였다. 본 연구에 사용한 각 실험사료의 조에너지 함량 및 일반성분은 차이 가 없었다(고 등, 2004). 크릴 밀 $2.0 \%$ 사료의 섭취량 증가와 성장율 감소가 사료의 에너지 함량이나 영양소 양 또는 종류의 차이에 의한 영향인지 분명히 알 수가 없었다.

본 연구에서 통계적인 평가는 하지 않았으나 파두유 주입은 사료중 크릴 밀 수준에 관계 없 이 간장과 비장 무게를 높이는 경향이 있었다. LPS 주입으로 면역반응을 활성화한 육계병아 리에서 크릴 밀 사료의 급여는 간장과 비장 무 게를 증가시켰다 (고 등, 2004; 박 등, 2004; 임 등 2007). 본 연구의 파두유 근육내 주입이 육 계병아리의 간장과 비장의 무게를 높이는 것은 LPS의 복강내 주입시와 동일하게 면역반응 활 성화가 원인인 것 같다. 파두유 주입은 혈장의 오보트랜스훼린 농도를 높였으므로 간장에서의 오보트랜스훼린 등의 급성기 단백질 합성 등의 방어반응의 활성화 그리고 비장내 면역세포 증 식의 자극이 간장과 비장 무게를 증가시키는 원인이라 생각된다.

\section{2. 혈중 TNF- $a$ 활성과 오보트렌스훼린 수준}

본 연구에서 크릴 밀 사료는 파두유 주입에 관계없이 육계병아리의 혈장 TNF- $a$ 활성을 크 릴 밀 $0.0 \%$ (기초)사료에 비해 유의하게 ( $\mathrm{p}<$ $0.05)$ 감소시켰다. LPS 급성기 반응 육계병아리 에서도 기초사료에 비해 크릴 밀 사료는 혈중 TNF-a 활성을 감소시켜(임 등, 2007b) 본 연구 의 파두유 주입시와 같았다. 크릴 밀은 어유와 비슷한 n-3 PUFA를 함유한다(고 등, 2004). 본 연구의 크릴 밀 사료 급여로 병아리 혈중 TNF- $a$ 활성 감소는 포유류에서 n-3 PUFA 급여로 친염증성 싸이토카인 분비가 감소하는 결과 (Fernandes 등, 1994, Jaya와 Chu, 1999 Calder, 1996 Endres 등, 1989)와 유사한 것 같다.

가금에서 파두유 주입은 혈중 IL-6과 급성기 단백질인 오보트렌스훼린의 분비를 증가시킨다 (Xie 등, 2002). 본 연구에서 오보트렌스훼린의 혈중 수준은 혈액 단백질중에서 항-가금 오보 트렌스훼린 항체와 반응하는 단백질 $65 \mathrm{kDa}$ 분 획으로 확인되었다(Xie 등 2000, 2002 임 등, 2007). 크릴 밀 $0.0 \%, 1.0 \%$ 및 $2.0 \%$ 사료를 급 여한 육계 병아리에서는, LPS주입 급성기 염증 반응중에 오보트랜스훼린의 혈중 농도가 대조 병아리보다 증가하여 (임 등, 2007). 급성기반응 이 오보트랜스훼린 농도에 미치는 크로톤오일 과 LPS의 영향은 동일하였다. 그러나 크릴 밀 $0.5 \%$ 사료를 급여한 병아리에서는, 혈액의 오 보트랜스훼린 농도가 대조에 비해서 LPS 주입 시는 낮았으나 (임 등, 2007) 크로톤오일 주입 시에는 높아지는 것이 달랐다. 이와 같이 혈중 오부트랜스 훼린 수준에 미치는 크로톤 오일과 LPS 급성기 반응(임 등, 2007)의 영향은 사료 중 크릴 밀 함량에 따라 달랐다.

\section{3. $\mathrm{PBMC}$ 와 비장세포 증식도}

포유류에서는 PBMC 와 비장세포의 $\mathrm{T}$ 임파 구가 세포성 면역의 연구에 이용된다. 포유류 의 $\mathrm{PBMC}$ 는 70 80\%의 $\mathrm{T}$ 임파구, $15 \sim 20 \%$ 의 B 임파구 및 $10 \%$ 의 단구세포(monocyte)와 NK 세 포(natural killer cell)로 구성된다 (Cochet 등, 1998). 그러나 가금의 PBMC를 구성하는 면역 세포의 비율은 잘 알려져 있지 않다. Bohls 등 (2006)은 flow cytometer를 이용한 분석에서 가 금의 PBMC는 $\mathrm{T}$ 임파구, B 임파구, NK세포 및 단구세포들로 구성되며 가금의 세포성 면역도 포유동물과 마찬가지로 $\mathrm{T}$ 임파구에 의해 작동 된다고 하였다. 본 연구실에서는 크릴 밀 사료 를 급여한 육계 병아리의 발가락 사이 피부의 PHA-p 반응으로 세포성 면역을 조사하였다 (고 등, 2004 박 등, 2004). 그러나 PHA-p 주입 후 부은 정도 측정을 위한 캘리퍼스 측정값의 
정밀도가 연구자의 숙련 정도에 따라 달라서 유의한 측정값을 얻기 위해서는 측정예수가 비 교적 많아야 하였다. 따라서 본 연구실에서는 알라마 블루 (alamar blue) 색소의 환원을 이용 한 비장세포와 $\mathrm{PBMC}$ 증식도 측정으로 세포성 면역을 평가하였다 (임 등, 2007a).

$\mathrm{PBMC}$ 증식도는 급성기 염증 반응중인 육계 병아리에서 근육내 파두유 주입과 복강내 LPS 주입시(임 등, 2007b)에 기초사료에 비해 크릴 밀 $0.5 \%$ 사료에서 유의하게 $(\mathrm{p}<0.05)$ 높았고, 크 릴 밀 수준이 1.0 및 2.0\%로 높아짐에 따라 유 의하게 낮아졌다. 이와 같이 급성기 염증 반응 중인 육계 병아리의 $\mathrm{PBMC}$ 증식도에 미치는 크릴 밀 수준의 영향은 파두유 주입과 LPS 주 입의 영향이 비슷하였다.

비장세포 증식도는 본 연구의 파두유 주입 급성기 반응중에는 크릴 밀 1.0 및 $2.0 \%$ 사료 에서 기초 및 크릴 밀 $0.5 \%$ 사료에 비해 유의 하게 낮았다. LPS 주입 급성기 염증 반응중(임 등, 2007b)에도 크릴 밀 1.0 및 $2.0 \%$ 사료는 크 릴 밀 $0.5 \%$ 사료보다 비장세포의 증식도를 낮 추었다. 크릴 밀 1.0 과 $2.0 \%$ 사료급여시에는 비 장세포 증식도가 LPS 주입과 파두유 주입 급 성기 염증 반응 양쪽에서 공통적으로 낮아졌 다, 그러나, LPS 주입시(임 등, 2007b)에 크릴 밀 $0.5 \%$ 사료는 비장세포 증식도를 기초사료보 다 높였으나, 크로톤 오일 주입시에는 크릴 밀 $0.5 \%$ 와 기초사료 사이에 차이가 없었다. 이와 같이 사료중 크릴 밀이 비장 세포 증식도에 미 치는 영향은 파두유 주입과 LPS 주입 급성기 염증 반응사이에 달랐다.

Peterson 등 (1998)는 사료중 낮은 수준 (4.4g $\mathrm{EPA}+\mathrm{DHA} / 100 \mathrm{~g}$ total fatty acids: n-6/n3 =7) 의 n-3 PUFA 급여는 마이토젠에 대한 $\mathrm{T}$ 와 $\mathrm{B}$ 임파구의 증식효과를 높이나, 높은 수준 $(6.6 \mathrm{~g}$ $\mathrm{EPA}+\mathrm{DHA} / 100 \mathrm{~g}$ total fatty acids: n-6 / n3 =7) 의 n-3 PUFA를 급여하면 임파구들의 증식이 감소하는 것을 관찰 하였다. Calder (1996)는 마 우스에 n-3 PUFA 급여시 Con A 및 PHA에 대한 임파구의 증식이 감소한다고 하였다. Schmidt 등 (1991)도 사람의 어유 섭취는 $\mathrm{T}$ 임 파구의 증식을 감소시킨다고 하였다. 본 연구
는 크릴 밀 $0.5 \%$ 사료급여시 $\mathrm{PBMC}$ 중의 $\mathrm{T}$ 임 파구의 증식이 다른 사료들에 비해 유의하게 증가하며, 크릴 밀 1.0 및 $2.0 \%$ 사료의 급여는 비장세포와 $\mathrm{PBMC}$ 모두에서 크릴 밀 $0.5 \%$ 사 료에 비해 유의하게 감소한다는 것을 나타낸 다. 이것은 $\mathrm{PBMC}$ 와 비장세포에서 육계병아리 가 섭취한 실험사료 중 n-3 PUFA 양의 증가에 따른 n-3 PUFA와 n-6 PUFA 비율의 변화에 의 한 것이라 추정된다. 본 연구에서 파두유 근육 내 주입에 의한 급성기 염증 반응중 $\mathrm{PBMC}$ 와 비장세포 증식도가 크릴 밀 $0.5 \%$ 사료급여로 증가하나 크릴 밀 1.0 및 $2.0 \%$ 사료 급여시 감 소하는 것은 크릴 밀중 함유된 n-3 지방산의 영향이라는 것을 시사한다.

본 연구는 파두유 주입에 의한 급성기 반응 중인 육계병아리에서 사료중 크릴 밀은 혈중 TNF-a 활성을 감소시켜서 급성기 반응의 부정 적 영향을 완화한다는 것을 나타낸다. 그러나, 파두유 주입시 면역반응에 미치는 크릴 밀의 영향은 오보트렌스훼린과 비장세포 증식도에서 LPS 주입시와는 달랐다.

이상과 같이 파두유 주입 육계병아리에서 크 릴 밀 사료는 혈중 TNF-a 활성을 감소시키나, 오보트렌스훼린 수준은 크릴 밀 수준과 관계없 이 높았다. 크릴 밀 사료는 파두유 주입시 $\mathrm{PBMC}$ 와 비장세포의 증식도를 변화시켰다. 혈 중 오보트렌스훼린 수준과 비장세포 증식도에 미치는 크릴 밀 사료의 영향은 LPS 주입시와 달랐으나, 본 연구는 사료중 크릴밀이 파두유 주입에 의해서 발생한 선천 면역과 세포성 면 역을 변화시킨다는 것을 나타내었다.

$$
\text { V. 요 약 }
$$

근육내 파두유를 주입한 육계병아리에서 사 료 중 크릴 밀 수준이 세포성 면역반응에 미치 는 영향을 조사하였다. 갓 부화한 육계병아리 (Ross) 수컷에 크릴 밀 0.0 (기초사료), 0.5, 1.0 및 $2.0 \%$ 사료를 급여하고 3 주간 사육하였다. 20일령에 $10 \mu \ell$ 의 파두유를 정강이 근육내에 주입하였고, 24시간 뒤 (21일령)에 혈중 TNF-a 활성과 오보트렌스훼린 수준 및 $\mathrm{PBMC}$ 와 비장 
Im et al. ; Interaction of Dietary Krill Meal with Croton Oil Injection in Cell Medieated Immunity of Broiler Chicks

세포의 증식도를 올리브유를 주입한 대조구와 비교하였다. 크릴 밀 사료는 육계병아리의 생 산성과 혈장 오보트렌스훼린 수준에 유의한 영 향을 미치지 않았으나, 크릴 밀 $0.0 \%$ 사료에 비해서 유의하게 $(\mathrm{p}<0.0001)$ 혈장 TNF- $\mathrm{a}$ 활성을 감소시키고 $\mathrm{PBMC}$ 증식도를 높였다. 비장 세포 증식도는 크릴 밀 $1.0 \%$ 사료에서 유의하게 $(\mathrm{p}=0.01)$ 높았다. 파두유 주입은 혈중 TNF-a 활 성 $(\mathrm{p}<0.0001)$, 오보트랜스훼린 수준 및 $\mathrm{PBMC}$ 증식도 $(\mathrm{p}<0.0001)$ 를 높였다. 파두유 주입 시에 $\mathrm{PBMC}$ 증식도는 사료중 크릴 밀 수준에 따라 점차 감소 $(\mathrm{p}<0.05)$ 하였고 비장세포 증식도는 크릴 밀 1.0 및 $2.0 \%$ 사료에서 유의하게 $(\mathrm{p}<$ 0.05) 감소하였다. 본 연구는 사료중 크릴밀이 파두유 주입으로 활성화한 선천 면역과 세포성 면역을 변화시킨다는 것을 나타내었다.

(색인: 파두유 (croton oil), tumor necrosis factor - $a(\mathrm{TNF}-\mathrm{a}), \mathrm{PBMC}$ 와 비장세포의 증식, 크릴 밀, 육계 병아리)

\section{VI. 인 용 문 헌}

1. Bohls, R. L., Smith, R., Ferro, P. J., Silvy, N. J., $\mathrm{Li}, \mathrm{Z}$. and Collisson, E. W. 2006. The use of flow cytometry to discriminate avian lymphocytes from contaminating thrombocytees, Develop. and Compera. Immun. 30:843-850.

2. Calder, P. C. 1996. Immunomodulatory and antiinflammatory effects of n-3 polyunsaturated fatty acids. Proc. Nutr. Soc. 55:737-774.

3. Cochet, O., Teillaud, J. L. and Sautes, C. 1998. Immunological techniques made easy. Wiley co, UK, pp.: 7.

4. Cook, M. E. 1991. Nutrition and the immune response of the domestic fowl. Crit. Rev. Poultry Biol. 3:167-189.

5. Edelman, A. S., Sanchez, P. L., Robinson, M. E., Hochwald, G. M. and Thorbecke, G. J. 1985. Primary and secondary wattle swelling response to phytohemagglutinin as a measure of immunocompetence in chickens. Avian Dis. 30:105-111.

6. Endres, S., Ghorbani, R. and Kelley, E. V. 1989.
The effect of dietary supplementation with n-3 polyunsaturated fatty acids on the synthesis of interleukin-1 and tumor necrosis factor by mononuclear cells. New Eng. J. Med. 320: 265271.

7. Fernandes, G., Bysami, C., Venkatraman, J. T., Tomar, V. and Zhao, W. 1994. Increased TGFß and decreased oncogene expression by $\omega 3$ lipids in the spleen delays autoimmune disease in $\mathrm{B} / \mathrm{W}$ mice. J. Immunol. 152:5979-5987.

8. Heuertz, R., Piquette, C. A. and Webster, R. O. 1993. Rabbits with elevated serum C-reactive protein exhibit diminished neutrophil infiltration and vascular permeability in C5a-induced alveolitis. Am. J. Pathol., 142: 319-328.

9. Jaya, T. V. and Wei-chia Chu. 1999. Effects of dietary $\omega 3$ and $\omega 6$ lipids and vitamin $\mathrm{E}$ on proliferative response, lymphoid cell subsets, production of cytokines by spleen cells, and splenic protein levels for cytokines and oncogenes in MRL/MpJ-lpr/lpr mice. J. Nutr. Biochem. 10: 582-597.

10. Klasing, K. C. 1994. Avian leukocytic cytokines. Poult. Sci. 73:1035-1043.

11. Korver, D. R. and Klasing, K. C. 1997. Dietary fish oil alters specific and inflammatory immune response. J. Nutr. 2039-2046.

12. Koutsos, E. A. and Klasing, K. C. 2001. Interactions between the immune system, nutrition, and productivity of animals. Pages 173-190 in: Recent Advances in Animal Nutrition, 2001, P.C. Garnsworthy and J. Wiseman, eds. Nittingham University Press, Nottingham.

13. Leshchinsky, T. V. and Klasing, K. C. 2001. Divergence of the inflammatory response in two types of chickens. Develop. and Comp. Immunol. 25:629-638.

14. Peterson, L. D., Thies, F., Sanderson, P., Newsholme, E. A. and Calder, P. C. 1998. Low levels of eicosapentaenoic and docosahexaenoic acids mimic the effects of fish oil upon rat lymphocytes. Life Sciences 62(24):2209-2217. 
Im et al. ; Interaction of Dietary Krill Meal with Croton Oil Injection in Cell Medieated Immunity of Broiler Chicks

15. Pettit, G. R. 1977. Biosynthetic products for cancer chemotherapy. vol1. Plenum press, New York, USA.

16. SAS Institute Inc. 1988. SAS user's Guide, statistics version 5 ed. SAS Institute Inc., NC, USA.

17. Schmidt, F. B., Pedersen, J. O., Varming, K., Ernst, E., Jersild, C., Grunnet, N. and Dyerberg, J. 1991. n-3 fatty acids and leukocyte chemotaxis. Effects in hyterlipidemia and dose-response studies in healthy men. Arteriosclerosis Thrombosis, 11:429-435.

18. Tohjo, H., Miyoshi, F., Uchida, E. and Nijyama, M. 1995. Polyacrylamide gel electrophoretic patterns of chicken serum in acute inflammation induced by intramuscular injection of turpentine, Poult. Sci., 74:648-655.

19. Xie, H., Rath, N. C., Huff, G. R., Balog, J. M. and Huff, W. E. 2000. Effects of Salmonella typhimurium lipopolysaccharide on brioler chickens. Poult. Sci. 79:33-40.

20. Xie H., Newberry, L., Clark, F. D., Huff, W. E., Huff, G. R., Balog, J. M. and Rath, N. C. 2002.
Change in serum ovotransferrin levels in chickens with experimentally induced inflammation and disease. Avian disease, 46:122-131.

21. 고태송, 임진택, 박인경, 김재환. 2004. 급성기 반 응중인 육계병아리의 생산성에 미치는 사료중 크릴 밀의 영향. 동물자원과학회지 46:173-182.

22. 박인경, 김재환, 임진택, 고태송. 2004. 사료중 크 릴 밀을 급여한 육계의 생산성과 $\mathrm{SOD}$ 활성에 미치는 급성기 반응의영향. 동물자원과학회지, 46:183-192.

23. 임진택, 김재환, 박인경, 고태송. 2003. 살모넬라 LPS를 주입한 육계병아리의 생산성과 질소밸런 스 및 대사에너지 이용성에 미치는 사료중 크릴 밀의 영향, 동물자원과학회지. 45:957-966.

24. 임진택, 박인경, 고태송. 2007a. Alamar blue 색소 의 환원량 평가에 의한 급성기 반응중 육계병아 리의 비장세포와 $\mathrm{PBMC}$ 증식도 측정. 동물자원 과학회지 49(2):213-224.

25. 임진택, 박인경, 고태송, 2007b. 살모넬라 LPS를 주입한 육계병아리에 있어서 생산성과 면역반응 에 미치는 사료중 크릴 밀 수준의 영향. 동물자 원과학회지 49(2):225-238.

(접수일자 : 2007. 5. 1. / 채택일자 : 2007. 9. 27.) 